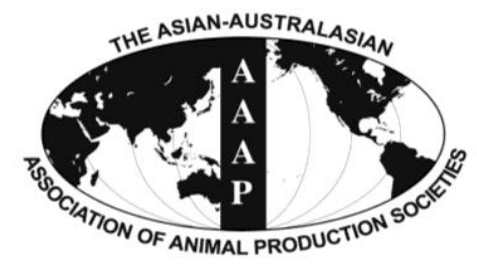

Asian-Aust. J. Anim. Sci.

Vol. 25, No. 7 : 962 - 970

July 2012

www.ajas.info

http://dx.doi.org/10.5713/ajas.2011.11442

\title{
Effects of Ruminal Infusion of Garlic Oil on Fermentation Dynamics, Fatty Acid Profile and Abundance of Bacteria Involved in Biohydrogenation in Rumen of Goats
}

\author{
Zhi Zhu, Shengyong Mao and Weiyun Zhu* \\ College of Animal Science and Technology, Nanjing Agricultural University, Nanjing 210095, China
}

\begin{abstract}
This study aimed to investigate the effects of ruminal infusion of garlic oil (GO) on fermentation dynamics, fatty acid (FA) profile, and abundance of bacteria involved in biohydrogenation in the rumen. Six wethers fitted with ruminal fistula were assigned to two groups for cross-over design with a 14-d interval. Each 30-d experimental period consisted of a 27-d adaptation and a 3-d sample collection. Goats were fed a basal diet without (control) or with GO ruminal infusion $(0.8 \mathrm{~g} / \mathrm{d})$. Ruminal contents collected before $(0 \mathrm{~h})$ and at 2, 4, 6, 8, and $10 \mathrm{~h}$ after morning feeding were used for fermentation analysis, and $0 \mathrm{~h}$ samples were further used for FA determination and DNA extraction. Garlic oil had no influence on dry matter intakes of concentrate and hay. During ruminal fermentation, GO had no effects on total VFA concentration and individual VFA molar proportions, whereas GO increased the concentrations of ammonia nitrogen and microbial crude protein $(\mathrm{p}<0.05)$. Compared with control, GO group took a longer time for total VFA concentration and propionate molar proportion to reach their respective maxima after morning feeding. The ratio of acetate to propionate in control reduced sharply after morning feeding, whereas it remained relatively stable in GO group. Fatty acid analysis showed that GO reduced saturated FA proportion ( $\mathrm{p}<0.05$ ), while increasing the proportions of C18, $t 11-18: 1$ (TVA), $c 9, t 11$-conjugated linoleic acid ( $c 9, t 11$-CLA), $t 10, c 12-\mathrm{CLA}$, and polyunsaturated FA (p<0.05). The values of TVA/( $c 9, t 11-\mathrm{CLA}+\mathrm{TVA})$ and C18:0/(TVA+ $\mathrm{C} 18: 0)$ were reduced by GO ( $\mathrm{p}<0.05)$. Real-time PCR showed that GO tended to reduce Butyrivibrio proteoclasticus abundance ( $\mathrm{p}=$ 0.058), whereas GO had no effect on total abundance of the Butyrivibrio group bacteria. A low correlation was found between B. proteoclasticus abundance and $\mathrm{C} 18: 0 /(\mathrm{TVA}+\mathrm{C} 18: 0)(\mathrm{p}=0.910)$. The changes of fermentation over time suggested a role of $\mathrm{GO}$ in delaying the fermentation process and maintaining a relatively modest change of ruminal environment. The inhibitory effects of GO on the final step of biohydrogenation may be related to its antibacterial activity against B. proteoclasticus and other unknown bacteria involved. (Key Words: Garlic Oil, Conjugated Linoleic Acid, Biohydrogenation, Butyrivibrio, Goat)
\end{abstract}

\section{INTRODUCTION}

Garlic (Allium sativum) has been used extensively in herbalism because of its well-known medicinal properties attributed to a number of active organosulphur compounds (Iciek et al., 2009). Recently, researches have shown the effects of garlic oil (GO) on in vitro batch fermentation (Busquet et al., 2005b; Cardozo et al., 2005) and in vitro continuous culture fermentation (Cardozo et al., 2004; Busquet et al., 2005a) with ruminal fluid. Busquet et al. (2005a, 2006) consistently showed that GO reduced the molar proportion of acetate and increased the molar proportions of propionate and butyrate. However, Cardozo et al. $(2004,2005)$ reported that $\mathrm{GO}$ had no effects on total

\footnotetext{
* Corresponding Author: Weiyun Zhu. Tel: +86-025-84395523, Fax: +86-025-84395314, E-mail: zhuweiyun@njau.edu.cn Submitted Nov. 22, 2011; Accepted Jan. 25, 2012; Revised Apr. 19, 2012
}

volatile fatty acid (VFA) concentration and molar proportions of individual VFA, or had $\mathrm{pH}$-dependent effects on 24-h ruminal fermentation. To date, only a few studies have investigated the in vivo effects of $\mathrm{GO}$ on ruminal fermentation, and the limited studies showed that GO had no significant effects on ruminal $\mathrm{pH}$, the concentrations of ammonia and total VFA, as well as the molar proportions of individual VFA in dairy cows (Yang et al., 2007) and lambs (Chaves et al., 2008). Collectively, the different responses to GO supplementation in in vitro and in vivo studies may be related to the dose and composition of GO used, as well as the rumen microbial environment and the adaptation time. Based on the wide spectrum of antibacterial activity of GO (Reuter et al., 1996), we hypothesized that GO may influence the dynamics of fermentation in the rumen.

Several gram-positive bacteria are involved in ruminal biohydrogenation of unsaturated dietary fatty acid (FA) 
(Harfoot and Hazlewood, 1997). The most active rumen bacterial species involved in $\mathrm{C} 18$ biohydrogenation belong to the "Butyrivibrio" group, where all bacteria form conjugated linoleic acid (CLA) from linoleic acid (LA), whereas only Clostridium proteoclasticum is able to convert t11-18:1 (TVA) to C18:0 (Polan et al., 1964; Kemp et al., 1975). C. proteoclasticum was recently reclassified as Butyrivibrio proteoclasticus (Moon et al., 2008). In the present study, we refer $C$. proteoclasticum to $B$. proteoclasticus. Therefore, selective inhibition of $B$. proteoclasticus, without affecting other bacteria in the "Butyrivibrio" group, would provide more unsaturated FA in the rumen. Due to the antibacterial activity (Reuter et al., 1996), GO may affect biohydrogenating bacterial abundance and the resulting FA profile in the rumen. However, to our best of knowledge, no information is available on whether GO could affect FA profile and abundance of bacteria involved in biohydrogenation in the rumen of goats.

Therefore, the objective of this study was to investigate the effects of ruminal infusion of GO on fermentation dynamics, FA profile and abundance of bacteria involved in biohydrogenation in the rumen.

\section{MATERIALS AND METHODS}

\section{Animals, experimental design, and diets}

Six wethers $(19.30 \pm 1.17 \mathrm{~kg}$ body weight (BW), mean \pm standard deviation), fitted with ruminal fistula, were assigned to two groups for cross-over design with a 14-d interval. Each experimental period lasted $30 \mathrm{~d}$, consisting of $27 \mathrm{~d}$ of adaptation and $3 \mathrm{~d}$ for sample collection. Goats were fed a basal diet without (control) or with GO infusion. Based on the dose of GO in lamb research $(0.01 \mathrm{~g} / \mathrm{kg} \mathrm{BW})$ (Chaves et al., 2008) and our previous study in Saanen dairy goats (0.01, 0.02 and $0.03 \mathrm{~g} / \mathrm{kg} \mathrm{BW})(\mathrm{Zhu}, 2011)$, the dose $0.04 \mathrm{~g} / \mathrm{kg}$ BW was used in the present research. Accordingly, the dose of GO for each goat was $0.8 \mathrm{~g} / \mathrm{d}$. The basal diet was formulated (Table 1) according to Feeding Standard of Meat-producing Sheep and Goats (NY/Y 8162004; Ministry of Agriculture, China, 2004) in order to fulfill requirements for the growth of goats. Diets for restricted intake consisted of grass hay (Leymus chinensis, $0.38 \mathrm{~kg} / \mathrm{d}$ dry matter $(\mathrm{DM}))$ and concentrate $(0.22 \mathrm{~kg} / \mathrm{d} \mathrm{DM})$. Once offering concentrate to the goat, GO product was infused directly and immediately by a 1-ml syringe via ruminal fistula. For each goat, the infusing lasted a few seconds. The ingestion of concentrate was completed simultaneously for each goat. Afterwards, hay was offered. Diet and GO infusion were offered in equal portions at 08:00 and 18:00 h. All goats had free access to fresh water throughout the experiment. The commercial GO (stored at $4^{\circ} \mathrm{C}$; Henan Yuanhua Biotechnology Co., Ltd., China) used
Table 1. Ingredient and chemical analysis of the experimental diets

\begin{tabular}{lcc}
\hline \multirow{2}{*}{ Composition } & \multicolumn{2}{c}{ Diet } \\
\cline { 2 - 3 } & Concentrate & Grass hay \\
\hline Ingredient $\left(\mathrm{g} / 100 \mathrm{~g} \mathrm{DM}^{1}\right)$ & - & 63.85 \\
$\quad$ Grass hay & 29.39 & - \\
Corn meal & 4.08 & - \\
Soybean meal & 1.75 & - \\
Wheat bran & 0.45 & - \\
Limestone & 0.48 & - \\
Salt & & \\
Chemical analysis $(\mathrm{g} / 100 \mathrm{~g} \mathrm{DM})$ & 90.68 & 89.00 \\
Dry matter $\%)$ & 11.73 & 7.30 \\
Crude protein & 3.43 & 3.40 \\
Ether extract & 10.54 & 57.10 \\
Neutral detergent fiber & 4.58 & 36.00 \\
Acid detergent fiber & 9.04 & 9.56 \\
Crude ash & 0.50 & 0.37 \\
Calcium & 0.35 & 0.18 \\
Phosphorus & &
\end{tabular}

in the experiment was produced by steam distillation $\left(150^{\circ} \mathrm{C}\right)$ which was used to collect the products that evaporate with steam. The main components of GO were sulfur compounds, such as the predominant diallyl trisulfide $(29.3 \%)$ and diallyl disulfide $(31.3 \%)$. No FA was detected in GO used in this study. Goats were fed individually in pens and managed in accordance with guidelines regarding animal care provided by the College of Animal Science and Technology in Nanjing Agricultural University.

\section{Sampling and chemical analysis}

Feed intake for individual goats was recorded on the last $3 \mathrm{~d}$ of each experimental period. Feed samples were dried at $65^{\circ} \mathrm{C}$ for $24 \mathrm{~h}$ in a forced-air oven, ground through a $1 \mathrm{~mm}$ screen, and analyzed for DM, crude ash content, ether extract and crude protein using standard procedures (AOAC, 1990). The concentrations of acid detergent fiber (ADF) and neutral detergent fiber (NDF) were determined by sequential procedures (pretreatment with $\alpha$-amylase for NDF) (Van Soest et al., 1991), and the results were expressed inclusive of residual ash.

Ruminal contents from multiple sites within the rumen of each animal were collected by suction via ruminal fistula before $(0 \mathrm{~h})$ and at 2, 4, 6, 8, and $10 \mathrm{~h}$ after morning feeding on the last $3 \mathrm{~d}$ of each period. The $\mathrm{pH}$ value was measured immediately using a portable $\mathrm{pH}$ meter (HI 8424; Hanna, Singapore). Then ruminal contents were collected into tubes. The 0 -h samples were collected in triplicate. The tubes were capped and placed in an ice bucket and immediately transferred to the laboratory. Duplicates of 0 -h samples 
were immediately stored at $-25^{\circ} \mathrm{C}$ for latter DNA extraction and FA analysis. The others were vortexed for $1 \mathrm{~min}$, and then centrifuged at $1,000 \times g$ for $10 \mathrm{~min}$. A 1-ml sample of the supernatant was acidified with $1 \mathrm{ml}$ of $0.2 \mathrm{~mol} / \mathrm{L} \mathrm{HCl}$ and frozen at $-25^{\circ} \mathrm{C}$ for latter ammonia nitrogen $\left(\mathrm{NH}_{3}-\mathrm{N}\right)$ analysis by spectrophotometer (UV-2450; Shimadzu, Japan) (Broderick and Kang, 1980). One $\mathrm{ml}$ of the supernatant was mixed with $0.2 \mathrm{ml} 25 \%(\mathrm{w} / \mathrm{v})$ metaphosphoric acid including crotonic acid $(64.64 \%$, w/v) as an internal standard and frozen at $-25^{\circ} \mathrm{C}$ for latter VFA analysis by gas chromatograph (GC-14B; Shimadzu, Japan) equipped with capillary column (Supelco 41491-03B, $30 \mathrm{~m} \times 0.32 \mathrm{~mm} \times$ $0.25 \mu \mathrm{m}$ film thickness; Bellefonte, USA) (Qin, 1982). One $\mathrm{ml}$ of the supernatant was stored at $-25^{\circ} \mathrm{C}$ for microbial crude protein (MCP) analysis by spectrophotometer (UV2450; Shimadzu, Japan) (Makkar et al., 1982).

Ruminal contents collected at $0 \mathrm{~h}$ on d 28, 29, and 30 were used for DNA extraction. Total DNA was extracted from $1.5 \mathrm{ml}$ homogenized ruminal contents by bead-beating for 3 min using a mini-bead beater (Biospec Products, USA), followed by phenol-chloroform extraction (Zoetendal et al., 1998). DNA was then precipitated with ethanol and pellet was resuspended in $70 \mu \mathrm{l}$ of Tris- $\mathrm{HCl} /$ EDTA (TE) buffer.

\section{Fatty acid analysis}

Ruminal contents collected at $0 \mathrm{~h}$ on d 28, 29, and 30 were used for FA determination. Lipid extraction was performed as described by Folch et al. (1957) with some modifications. Briefly, the homogenized ruminal contents $(10 \mathrm{~g})$ were mixed with $20 \mathrm{ml}$ chloroform/methanol (2/1, $\mathrm{v} / \mathrm{v})$. After dispersion, the whole mixture was agitated for $20 \mathrm{~min}$ in an orbital shaker at room temperature. The homogenate was centrifuged $(1,200 \times g$ for $10 \mathrm{~min})$ to recover the liquid phase. Then the liquid phase was washed with $5 \mathrm{ml} 0.9 \% \mathrm{NaCl}$ solution. After vortexing $2 \mathrm{~min}$, the mixture was centrifuged at $1,200 \times g$ for $10 \mathrm{~min}$ to separate the two phases. The upper phase was removed by siphoning, the lower chloroform phase containing lipid was evaporated at $50^{\circ} \mathrm{C}$ under nitrogen. Methylation of FA was performed with $2 \mathrm{ml} 0.5 \mathrm{~mol} / \mathrm{L}$ methanolic $\mathrm{KOH}$, followed by rocking (about $3 \mathrm{~min}$ ) in a water bath at $50^{\circ} \mathrm{C}$ under nitrogen until the oil beads disappeared. The flasks were cooled and then $2 \mathrm{ml} 14 \%$ boron trifluoride/methanol was added. Afterwards, the flasks were incubated in a water bath at $50^{\circ} \mathrm{C}$ under nitrogen for $3 \mathrm{~min}$. After cooling, one $\mathrm{ml}$ $\mathrm{n}$-heptane was added followed by vortexing. The upper organic phase was rinsed with saturated $\mathrm{NaCl}$ solution, and then transferred to 2-ml centrifuge tube containing anhydrous sodium sulfate.

Fatty acid methyl esters were analyzed according to the reported methods (Lu et al., 2005; Lou et al., 2010) with some modifications using a gas chromatography (6890N series; Agilent Technology, USA) equipped with mass spectrometry (5973 series; Agilent Technology, USA). Fatty acid separation was performed on a fused silica capillary column (HP-5MS, $100 \mathrm{~m} \times 0.25 \mathrm{~mm} \times 0.20 \mu \mathrm{m}$; Supelco, Bellefonte, USA). Ultrapure helium was used as carrier gas, the injector pressure was held constant at $43.9 \mathrm{kPa}$. Analysis of FA required injection of $1 \mu \mathrm{l}$ with split ratio of $10: 1$ at a constant flow rate of $1 \mathrm{ml} / \mathrm{min}$ by carrier gas. Injector temperature was maintained at $280^{\circ} \mathrm{C}$. Initial column temperature was $80^{\circ} \mathrm{C}$, increased to $220^{\circ} \mathrm{C}$ at a rate of $6^{\circ} \mathrm{C} / \mathrm{min}$ (held for $13 \mathrm{~min}$ ), and then raised at $10^{\circ} \mathrm{C} / \mathrm{min}$ to a final temperature of $280^{\circ} \mathrm{C}$ (held for $15 \mathrm{~min}$ ). The electronimpact ionization mass spectrometer was operated as follows: ionization voltage, $70 \mathrm{eV}$; ion source temperature, $230^{\circ} \mathrm{C}$; mass scan range, 29 to 450 . Mass spectral identification of FA was carried out by comparing spectra with those in the NIST98 (National Institute of Standards and Technology, USA). Results for each FA were expressed as a percentage of the sum of all identified FA.

\section{Real-time PCR}

Real-time PCR was performed on an ABI 7300 system (Applied Biosystems, USA) associated with 7300 Sequence Detection Systems Software (version 2.2.1; Applied Biosystems, USA). The primers described below were synthesized and the PCR reagents were provided by Sangon (Sangon Biotech Co., Ltd., China).

According to the method from Boeckaert et al. (2008), $16 \mathrm{~S}$ rRNA gene of the Butyrivibrio group of bacteria was quantified by Butyrivibrio-specific forward and reverse primers B395f (5'-GYG AAG AAG TAT TTC GGT AT-3') and B812r (5'-CCA ACA CCT AGT ATT CAT C-3'), respectively. Quantitative PCR (qPCR) reaction mixture (20 $\mu \mathrm{l})$ consisted of $10 \mu \mathrm{l}$ of $2 \times$ FastStart Universal SYBR Green Master (Roche Applied Science, Germany), $0.6 \mu \mathrm{l}$ forward primer $(10 \mu \mathrm{mol} / \mathrm{L}), 0.6 \mu \mathrm{l}$ reverse primer $(10$ $\mu \mathrm{mol} / \mathrm{L}), 2 \mu \mathrm{l}$ DNA and $6.8 \mu \mathrm{l}$ PCR-grade $\mathrm{H}_{2} \mathrm{O}$. Quantitative PCR amplification was performed using the following conditions: 1 cycle of $2 \mathrm{~min}$ at $50^{\circ} \mathrm{C}, 10 \mathrm{~min}$ at $95^{\circ} \mathrm{C}, 40$ cycles of $15 \mathrm{~s}$ at $95^{\circ} \mathrm{C}, 30 \mathrm{~s}$ at $55^{\circ} \mathrm{C}$, and $45 \mathrm{~s}$ at $72^{\circ} \mathrm{C}$. Quantification of $16 \mathrm{~S}$ rRNA gene copies in each sample was performed in triplicate, and the mean value was calculated. The Butyrivibrio group bacterial 418-bp PCR product amplified by specific primers (Boeckaert et al., 2008) from the strain B. fibrisolvens DSM 3071 was used as a template for standard curves. Standard curves were constructed using at least five different 10-fold serial dilutions of PCR product ranging from 9.82 copies to $9.82 \times 10^{7}$ copies of product per $\mu \mathrm{l}$. The efficiency of amplification was calculated as follows: efficiency = $\left(10^{(-1 / \text { slope })}-1\right)$. The bacterial $16 \mathrm{~S}$ rRNA gene copies were 
plotted against the $\mathrm{C}_{\mathrm{T}}$ value used to estimate the number of copies in each sample. PCR reaction mixture $(50 \mu \mathrm{l})$ consisted of $1 \mu \mathrm{l}$ DNA extract, $1 \mu$ of each primer (10 $\mu \mathrm{mol} / \mathrm{L}), 1 \mu \mathrm{l}$ deoxynucleotide triphosphate mixture (10 mmol/L each), $5 \mu \mathrm{l} 10 \times \mathrm{PCR}$ amplification buffer (50 $\mathrm{mmol} / \mathrm{L} \mathrm{KCl}, 10 \mathrm{mmol} / \mathrm{L}$ Tris- $\mathrm{HCl} \mathrm{pH} 8.5,0.1 \%$ Triton $\mathrm{X}$ 100), $6 \mu \mathrm{MgCl}_{2}$ (25 mmol/L), $0.25 \mu \mathrm{l} \mathrm{Taq} \mathrm{polymerase} \mathrm{(5}$ $\mathrm{U} / \mu \mathrm{l}$ ) and lastly PCR-grade $\mathrm{H}_{2} \mathrm{O}$. PCR amplification was carried out in Eppendorf Mastercycler ${ }^{\circledR}$ Gradient (Eppendorf, Germany), with an initial DNA denaturation step at $94^{\circ} \mathrm{C}$ for $5 \mathrm{~min}$, followed by 34 cycles of denaturation at $94^{\circ} \mathrm{C}$ for $30 \mathrm{~s}$, annealing at $55^{\circ} \mathrm{C}$ for $30 \mathrm{~s}$, and extension at $72^{\circ} \mathrm{C}$ for $40 \mathrm{~s}$, and final extension at $72^{\circ} \mathrm{C}$ for $7 \mathrm{~min}$. The amplicons were measured in triplicate using a NanoDrop-1000 spectrophotometer (Labtech International, UK) and analyzed by electrophoresis on a $1.5 \%$ agarose gel $(\mathrm{w} / \mathrm{v})$ containing ethidium bromide.

Quantification of $B$. proteoclasticus was conducted according to Paillard et al. (2007) using forward (SA-FW, 5'-TCC GGT GGT ATG AGA TGG GC-3') and reverse (SA-RV, 5'-GTC GCT GCA TCA GAG TTT CCT-3') primers. Reaction mixture $(20 \mu \mathrm{l})$ consisted of $10 \mu \mathrm{l}$ of $2 \times$ FastStart Universal Probe Master (Roche Applied Science, Germany), $0.8 \mu \mathrm{l}$ forward primer SA-FW (10 $\mu \mathrm{mol} / \mathrm{L}), 1.6 \mu \mathrm{l}$ reverse primer SA-RV $(10 \mu \mathrm{mol} / \mathrm{L}), 0.5 \mu \mathrm{l}$ molecular beacon probe (5'-FAM-CCG CTT GGC CGT CCG ACC TCT CAG TCC GAG CGG-DABCYL-3') (Invitrogen, China) $(10 \mu \mathrm{mol} / \mathrm{L}), 2 \mu \mathrm{l}$ DNA and $5.1 \mu \mathrm{l} \mathrm{PCR}-$ grade $\mathrm{H}_{2} \mathrm{O}$. The qPCR amplification program was the same as for the Butyrivibrio group bacteria. Dilutions of PCR product (1,506 bp) amplified by forward 8f (5'-AGA GTT TGA TCC TGG CTC AG-3') and reverse 1510r (5'-GGC TAC CTT GTT ACG A-3') primers (Ding and Yokota, 2004) from 16S rRNA gene clone A23 (accession No. HQ326602) were used for constructing specific standard curves. The 10 -fold serial dilutions of PCR product ranged from 6.06 copies to $6.06 \times 10^{7}$ copies of product per $\mu$ l. The PCR amplification mixture of clone A23 was the same as for B. fibrisolvens DSM 3071. Amplification conditions were as follows: $94^{\circ} \mathrm{C}$ for $3 \mathrm{~min}, 30$ cycles of $94^{\circ} \mathrm{C}$ for $30 \mathrm{~s}$, $57^{\circ} \mathrm{C}$ for $30 \mathrm{~s}$ and $68^{\circ} \mathrm{C}$ for $1.5 \mathrm{~min}$, and a final extension of $68^{\circ} \mathrm{C}$ for $7 \mathrm{~min}$. The amplicons were measured and analyzed as above.

\section{Statistical analysis}

Data were analyzed using PROC MIXED of SAS (version 8.01; SAS Institute, Inc., USA) (SAS, 2000) according to the model $Y_{i j k}=\mu+G_{i}+P_{j}+T_{k}+e_{i j k}$, where $Y_{i j k}$ was the response variable, $\mu$ was the overall mean, $G_{i}$ was the random effect of goat $i, P_{j}$ was the effect of period $j, T_{k}$ was the effect of treatment $\mathrm{k}$, and $\mathrm{e}_{\mathrm{ijk}}$ was the random residual error. For the statistical analysis of ruminal fermentation characteristics $\left(\mathrm{pH}, \mathrm{NH}_{3}-\mathrm{N}, \mathrm{MCP}\right.$, and VFA), sampling time $\left(\mathrm{H}_{\mathrm{r}}\right)$ and interaction of treatment with sampling time $(\mathrm{T} \times \mathrm{H})_{\mathrm{kr}}$ were added to the model, and analyzed using repeated measures of PROC MIXED with the covariance type auto-regressive order 1 (AR (1)). The effect of sampling time was repeated measures. Means were separated by using the PDIFF option in the LSMEAS statement. Pearson correlation was analyzed using PROC CORR procedure to investigate the relationship between microbial abundance and FA proportion in the rumen. Significances were determined at $\mathrm{p}<0.05$; differences of $\mathrm{p}<0.1$ were discussed as trend.

\section{RESULTS}

\section{Feed intake}

No refusals of concentrate in the two groups were observed. The DM intake of concentrate for each goat was $0.22 \mathrm{~kg} / \mathrm{d}$. Garlic oil had no influence on the intake of hay $(0.33 \mathrm{~kg} / \mathrm{d}$ for control and $0.32 \mathrm{~kg} / \mathrm{d}$ for GO group).

\section{Ruminal fermentation}

The effects of GO on ruminal fermentation are shown in Table 2. A slight reduction $(\mathrm{p}<0.05)$ in ruminal $\mathrm{pH}$ was found in GO group (6.49) as compared with control (6.55).

Table 2. Effects of garlic oil on ruminal fermentation

\begin{tabular}{|c|c|c|c|c|c|c|}
\hline \multirow{2}{*}{ Item } & \multicolumn{2}{|c|}{ Treatment } & \multirow{2}{*}{ SEM } & \multicolumn{3}{|c|}{$\mathrm{p}$} \\
\hline & Control & Garlic & & Treatment & Time & Treatment $\times$ time \\
\hline $\mathrm{pH}$ & 6.55 & 6.49 & 0.011 & 0.012 & $<0.001$ & 0.673 \\
\hline $\mathrm{NH}_{3}-\mathrm{N}(\mathrm{mmol} / \mathrm{L})$ & 6.49 & 8.02 & 0.177 & $<0.001$ & $<0.001$ & 0.219 \\
\hline $\mathrm{MCP}(\mu \mathrm{g} / \mu \mathrm{l})$ & 1.54 & 1.91 & 0.035 & $<0.001$ & $<0.001$ & 0.510 \\
\hline Total VFA (mmol/L) & 73.18 & 69.93 & 0.529 & 0.054 & $<0.001$ & 0.017 \\
\hline \multicolumn{7}{|l|}{ VFA (mol/100 mol) } \\
\hline Acetate & 66.64 & 67.46 & 0.210 & 0.140 & 0.059 & 0.068 \\
\hline Propionate & 21.54 & 20.99 & 0.304 & 0.547 & $<0.001$ & 0.014 \\
\hline Butyrate & 11.82 & 11.56 & 0.160 & 0.622 & 0.001 & 0.503 \\
\hline Acetate/propionate & 3.31 & 3.29 & 0.049 & 0.911 & $<0.001$ & 0.008 \\
\hline
\end{tabular}

$\mathrm{NH}_{3}-\mathrm{N}=$ Ammonia nitrogen; $\mathrm{MCP}=$ Microbial crude protein; Total VFA = Acetate+propionate+butyrate; SEM = Standard error of mean; $\mathrm{p}=$ Probability. 
There were increases $(p<0.05)$ in the concentrations of $\mathrm{NH}_{3}-\mathrm{N}$ and MCP upon GO infusion. Garlic oil had no influence on total VFA concentration, molar proportions of individual VFA, or ratio of acetate to propionate. There were interactions between treatment and sampling time for total VFA concentration, propionate molar proportion and ratio of acetate to propionate $(\mathrm{p}<0.05)$. The temporal changes showed that total VFA concentration and propionate molar proportion reached maxima at $2 \mathrm{~h}$ after morning feeding in control, whereas the maxima occurred at $6 \mathrm{~h}$ in GO group (Figure 1). The ratio of acetate to propionate in control reduced sharply after morning feeding,
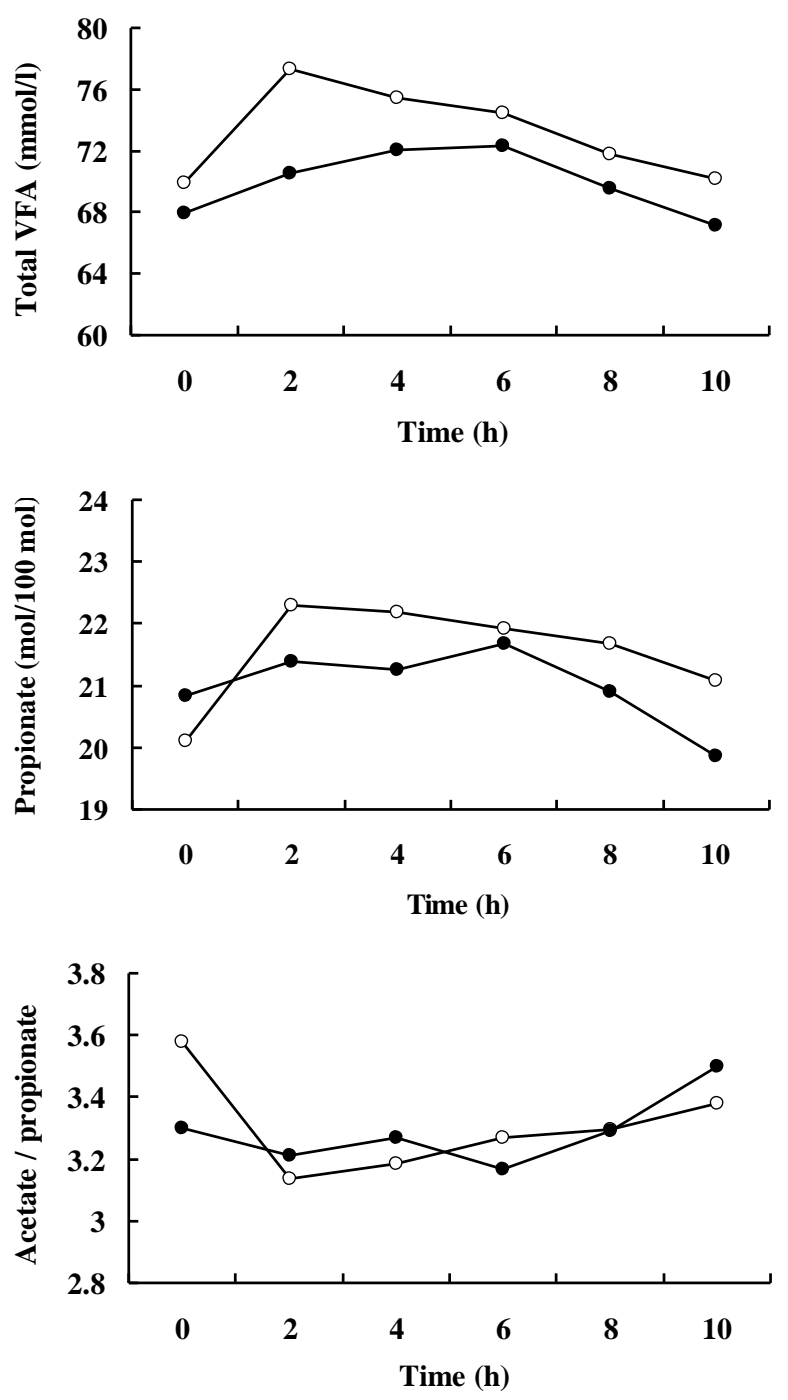

Figure 1. Temporal changes in total VFA concentration, propionate molar proportion, and ratio of acetate to propionate in goats fed basal diet (corn-soybean meal concentrate and Leymus chinensis) without (०) or with garlic oil infusion $(\bullet, 0.8 \mathrm{~g} / \mathrm{d})$ via ruminal fistula. Values represent the means from 6 goats for 3-d sample collection. Standard error of mean $=0.529 \mathrm{mmol} / \mathrm{L}, 0.304$ $\mathrm{mol} / 100 \mathrm{~mol}$, and 0.049 for total VFA concentration, propionate molar proportion, and ratio of acetate to propionate, respectively. Total VFA = Acetate+propionate+butyrate. whereas it remained relatively stable in GO group (Figure 1).

\section{Fatty acid proportion}

Details regarding FA proportion are summarized in Table 3. Generally, GO had no effects on C4 to C14 FA proportions, while reducing $\mathrm{C} 15$ and $\mathrm{C} 16 \mathrm{FA}$ proportions $(p<0.05)$ and increasing the proportions of C18 FA, TVA,

Table 3. Effects of garlic oil on fatty acid proportion in ruminal contents

\begin{tabular}{|c|c|c|c|c|}
\hline \multirow{2}{*}{ Fatty acid (\%) } & \multicolumn{2}{|c|}{ Treatment } & \multirow{2}{*}{ SEM } & \multirow{2}{*}{$\mathrm{p}$} \\
\hline & Control & Garlic & & \\
\hline $\mathrm{C} 4: 0$ & 2.64 & 2.59 & 0.017 & 0.185 \\
\hline C6:0 & 1.73 & 1.70 & 0.013 & 0.225 \\
\hline C8:0 & 1.14 & 1.11 & 0.015 & 0.246 \\
\hline C10:0 & 1.20 & 1.18 & 0.017 & 0.253 \\
\hline C12:0 & 3.00 & 2.97 & 0.018 & 0.279 \\
\hline $\mathrm{C} 14: 0$ & 7.27 & 7.24 & 0.018 & 0.333 \\
\hline C15:0 & 1.13 & 1.06 & 0.014 & $<0.001$ \\
\hline $\mathrm{C} 15: 1$ & 0.77 & 0.75 & 0.006 & 0.008 \\
\hline C16:0 & 32.97 & 32.60 & 0.080 & $<0.001$ \\
\hline $\mathrm{C} 16: 1$ & 1.63 & 1.54 & 0.014 & $<0.001$ \\
\hline $\mathrm{C} 17: 0$ & 0.38 & 0.37 & 0.003 & 0.052 \\
\hline $\mathrm{C} 17: 1$ & 0.26 & 0.26 & 0.003 & 0.553 \\
\hline C18:0 & 13.27 & 13.50 & 0.032 & $<0.001$ \\
\hline C18:1 & 22.12 & 22.44 & 0.096 & 0.033 \\
\hline TVA & 0.32 & 0.33 & 0.001 & $<0.001$ \\
\hline C18:2 & 1.24 & 1.32 & 0.010 & $<0.001$ \\
\hline $\mathrm{C} 18: 3$ & 0.70 & 0.76 & 0.007 & $<0.001$ \\
\hline$c 9, t 11$-CLA & 0.14 & 0.15 & 0.002 & $<0.001$ \\
\hline$t 10, c 12-$ CLA & 0.02 & 0.03 & 0.001 & 0.035 \\
\hline C20:0 & 0.14 & 0.15 & 0.002 & $<0.001$ \\
\hline C20:1 (n-9) & 0.25 & 0.28 & 0.004 & $<0.001$ \\
\hline C20:2 (n-6) & 0.15 & 0.16 & 0.002 & $<0.001$ \\
\hline C20:4 (n-6) & 0.08 & 0.10 & 0.003 & $<0.001$ \\
\hline C20:5 (n-3) & 0.06 & 0.08 & 0.003 & $<0.001$ \\
\hline C22:1 (n-9) & 0.14 & 0.15 & 0.002 & 0.019 \\
\hline $\mathrm{C} 22: 3(\mathrm{n}-3)$ & 0.02 & 0.03 & 0.001 & 0.005 \\
\hline $\mathrm{C} 22: 5(\mathrm{n}-3)$ & 0.02 & 0.03 & 0.001 & $<0.001$ \\
\hline $\mathrm{C} 22: 6(n-3)$ & 0.07 & 0.09 & 0.002 & $<0.001$ \\
\hline C24:1 (n-9) & 0.01 & 0.02 & 0.001 & 0.001 \\
\hline Total other & 7.13 & 7.03 & 0.034 & 0.052 \\
\hline SFA & 64.86 & 64.48 & 0.104 & 0.004 \\
\hline MUFA & 25.50 & 25.75 & 0.099 & 0.076 \\
\hline PUFA & 2.51 & 2.74 & 0.023 & $<0.001$ \\
\hline TVA/( $c 9, t 11-C L A+T V A)$ & 70.11 & 69.24 & 0.237 & 0.021 \\
\hline C18:0/(TVA+C18:0) & 97.64 & 97.61 & 0.006 & 0.040 \\
\hline
\end{tabular}

$\mathrm{TVA}=t 11-18: 1 ;$ CLA $=$ Conjugated linoleic acid; SFA $=$ C4:0+C6:0+ $\mathrm{C} 8: 0+\mathrm{C} 10: 0+\mathrm{C} 12: 0+\mathrm{C} 14: 0+\mathrm{C} 15: 0+\mathrm{C} 16: 0+\mathrm{C} 17: 0+\mathrm{C} 18: 0+\mathrm{C} 20: 0 ; \quad$ MUFA $=\mathrm{C} 15: 1+\mathrm{C} 16: 1+\mathrm{C} 17: 1+\mathrm{C} 18: 1+t 11-18: 1+\mathrm{C} 20: 1(\mathrm{n}-9)+\mathrm{C} 22: 1(\mathrm{n}-9)+\mathrm{C} 24: 1$ $(\mathrm{n}-9) ;$ PUFA $=\mathrm{C} 18: 2+\mathrm{C} 18: 3+c 9, t 11-\mathrm{CLA}+t 10, c 12-\mathrm{CLA}+\mathrm{C} 20: 2(\mathrm{n}-6)+$ $\mathrm{C} 20: 4(\mathrm{n}-6)+\mathrm{C} 20: 5(\mathrm{n}-3)+\mathrm{C} 22: 3(\mathrm{n}-3)+\mathrm{C} 22: 5(\mathrm{n}-3)+\mathrm{C} 22: 6(\mathrm{n}-3) ; \mathrm{SEM}=$ Standard error of mean; $\mathrm{p}=$ Probability. 
$c 9, t 11-$ CLA and $t 10, c 12-$ CLA $(\mathrm{p}<0.05)$ in the rumen. Garlic oil reduced saturated FA (SFA) proportion $(\mathrm{p}<0.05)$, whereas GO increased polyunsaturated FA (PUFA) proportion $(\mathrm{p}<0.05)$ and tended to increase monounsaturated FA (MUFA) proportion $(\mathrm{p}=0.076)$. The values of TVA/ $(c 9, t 11-\mathrm{CLA}+\mathrm{TVA})$ and $\mathrm{C} 18: 0 /$ (TVA+ C18:0) were reduced by GO $(\mathrm{p}<0.05)$.

\section{Bacterial abundance}

The abundance of Butyrivibrio group bacteria and B. proteoclasticus in ruminal contents is listed in Table 4. Quantitative PCR efficiency for all assays was between $90 \%$ and $110 \%$ (data not shown). Correlations of DNA standards for all real time PCRs were >0.97 (data not shown). Results showed that GO had no influence on the Butyrivibrio group bacterial abundance, whereas GO tended to reduce $B$. proteoclasticus abundance $(p=0.058)$. Correlation analysis showed that there was a low correlation between $B$. proteoclasticus abundance and C18:0/(TVA+ C18:0) $(r=0.02, \mathrm{p}=0.910)$.

\section{DISCUSSION}

Since garlic has been shown to exhibit a wide spectrum of antibacterial activity (Reuter et al., 1996), a high dose of GO could have detrimental effects on ruminal fermentation as suggested by Yang et al. (2007). In this study, the dose of GO per body weight was higher than those investigated in growing lambs (Chaves et al., 2008) and lactating cows (Yang et al., 2007). In the current research, the DM intake in goat was not affected by GO infusion. This result suggested that the dose of GO used in this study had no detrimental effects on digestion of feed. Meanwhile, a longer adaptation of rumen to the presence of GO may partly explain the lack of effects on intake of diets.

Previous researches have shown that rumen fermentation could be adapted to the addition of GO. Cardozo et al. (2004) found that GO modified the molar proportions of individual VFA between $\mathrm{d} 2$ to 6 of fermentation in a dual-flow continuous-culture fermentor system, but all these effects disappeared after 6-d adaptation. In in vitro continuous culture trials, total VFA concentration, individual VFA molar proportions, and $\mathrm{NH}_{3}-\mathrm{N}$ concentration in fermentation changed during the first $2 \mathrm{~d}$ after the addition of $\mathrm{GO}$, but remained stable thereafter

Table 4. Effects of garlic oil on 16S rRNA gene copies of ruminal bacteria ( $\log 10$ copies/ml ruminal contents)

\begin{tabular}{|c|c|c|c|c|}
\hline \multirow{2}{*}{ Bacteria } & \multicolumn{2}{|c|}{ Treatment } & \multirow{2}{*}{ SEM } & \multirow{2}{*}{$\mathrm{p}$} \\
\hline & Control & Garlic & & \\
\hline Butyrivibrio group bacteria & 11.78 & 11.52 & 0.195 & 0.427 \\
\hline Butyrivibrio proteoclasticus & 9.81 & 9.43 & 0.106 & 0.058 \\
\hline
\end{tabular}

(Busquet et al., 2005a, b). The different adaptation time may be due to the different concentration of GO used in experiments. In addition, Castillejos et al. (2007) demonstrated that VFA concentration and proportions only required a short adaptation time, longer than $24 \mathrm{~h}$ but shorter than $6 \mathrm{~d}$, whereas $\mathrm{N}$ metabolism required an adaptation time of up to 4 wks, which may suggest that the microbial populations associated with $\mathrm{N}$ metabolism changed relatively slowly. In the current study, ruminal contents collected after 27-d adaptation were feasible for analyzing dynamics of fermentation.

Studies of plant essential oil to ruminant nutrition have been focused on their potentials to improve nitrogen and energy utilization in the rumen (Benchaar et al., 2008). In the present research, GO increased $\mathrm{NH}_{3}-\mathrm{N}$ concentration in the rumen. However, the in vivo studies showed that GO just numerically reduced (Chaves et al., 2008) or increased (Yang et al., 2007) $\mathrm{NH}_{3}-\mathrm{N}$ concentration in the rumen of growing lambs and lactating cows, respectively. Interestingly, in 24-h batch culture fermentation, Busquet et al. (2005b) found that some doses (e.g. 3 to $300 \mathrm{mg} / \mathrm{L}$ ) of $\mathrm{GO}$ and its compounds increased $\mathrm{NH}_{3}-\mathrm{N}$ concentration, whereas the high dose $(3,000 \mathrm{mg} / \mathrm{L})$ of compounds reduced $\mathrm{NH}_{3}-\mathrm{N}$ concentration. On the contrary, Cardozo et al. (2005) found that $\mathrm{GO}$ ( 3 to $300 \mathrm{mg} / \mathrm{L}$ ) reduced $\mathrm{NH}_{3}-\mathrm{N}$ concentration of the 24-h fermentation culture with different initial $\mathrm{pH}$ (7.0 and 5.5). Therefore, the discrepancy among these studies is probably due to the actual concentration and chemical composition of GO, as well as experimental conditions (including animal condition, diets/substrate and adaptation time) used in studies. It was reported that $\mathrm{NH}_{3}-\mathrm{N}$ formation is affected only at the last step of the breakdown sequence of protein, that is the deamination of amino acids (Wallace, 2004). In this study, the increase of $\mathrm{NH}_{3}-\mathrm{N}$ concentration during fermentation suggested that GO seemed to stimulate the deamination. Meanwhile, reduction in $\mathrm{NH}_{3}-\mathrm{N}$ absorption by rumen epithelium could also cause the increase of $\mathrm{NH}_{3}-\mathrm{N}$ concentration in the rumen. It is known that $\mathrm{NH}_{3}-\mathrm{N}$ is regarded to be the most important nitrogen source for microbial protein synthesis in the rumen (Wanapat et al., 2008). The concentrations of $\mathrm{NH}_{3}-\mathrm{N}$ obtained in the present study (201.19 and $248.62 \mathrm{mg} / \mathrm{L})$ were close to the optimal ruminal $\mathrm{NH}_{3}-\mathrm{N}$ (150 to $300 \mathrm{mg} / \mathrm{L}$ ) (Wanapat et al., 2011). Increased $\mathrm{NH}_{3}-\mathrm{N}$ concentration in $\mathrm{GO}$ group may benefit microbial protein synthesis, as observed in the increased level of MCP. Nevertheless, further study is needed to investigate the mechanism of increased $\mathrm{NH}_{3}-\mathrm{N}$ and MCP concentrations by GO.

Although reduction in $\mathrm{pH}$ was found in $\mathrm{GO}$ group, this difference between the treatments was marginal (6.55 and 6.49). Such a small change of $\mathrm{pH}$ could be considered similar in the rumen. Yang et al. (2007) stated that a high 
dose of GO could have detrimental effects on ruminal fermentation. At present, no influence on the intake and total VFA concentration were found, suggesting that the dose of GO used may not be harmful to the rumen after adaptation. Owing to the antibacterial activity (Reuter et al., 1996), the sensitive bacteria are readily inhibited by GO. From a long-term continuous culture study, Busquet et al. (2005b) suggested that after longer adaptation, the microbial population inhibited by GO may be replaced by other resistant bacterial groups, leading to the lack of detrimental effects reported in in vitro continuous culture systems (Cardozo et al., 2004; Busquet et al., 2005a, b). Thus, in the present study, the lack of effects of GO on total VFA concentration and individual VFA molar proportions may be due to the long adaptation time $(27 \mathrm{~d})$ for the ruminal microflora.

An interesting finding of this study is that the effectiveness of GO on ruminal fermentation related to the time after infusion. Garlic oil supplementation seemed to delay the fermentation process as evidenced by a delayed occurrence of maximal total VFA concentration and molar proportion of propionate as compared with control. While the ratio of acetate to propionate in control reduced sharply after morning feeding, this ratio in GO group remained relatively stable, suggesting that $\mathrm{GO}$ could maintain a modest change of ruminal environment during fermentation. These interesting findings may be due to the antibacterial activity of GO, which might affect the abundance and activity of microorganisms after feeding. Rapid fermentation usually takes place after feeding, especially when diets contain high proportions of concentrates. Thus, GO may have the potential for its use as additives to prevent the rapid change of ruminal environment during fermentation.

To our knowledge, no information is available on the effects of GO on FA profile in the rumen. This study, for the first time, investigated GO effects on FA proportion and abundance of bacteria involved in biohydrogenation, and then explored the possible mechanism of GO effects on biohydrogenation. In the rumen, dietary lipids are subject to hydrolysis by microbial lipases (Jenkins et al., 2008; Lourenço et al., 2010). Here, the higher proportions of $\mathrm{C} 18: 1, \mathrm{C} 18: 2$ and $\mathrm{C} 18: 3$ in GO group compared with control may be related to a GO effect on lipolysis in the rumen. Whether GO inhibits lipolysis or not requires further investigation. The free FA from lipolysis, both saturated and unsaturated, can be sequestered into microbial cells for lipid synthesis (Harfoot and Hazlewood, 1997). Thus, the modifications of FA profile by GO in the current study may be in part attributed to its effects on lipid synthesis in microorganisms. The major microbial transformations in the rumen are de novo synthesis of odd- and branched-chain FA and biohydrogenation of unsaturated FA (Kim et al., 2005).
As no FA was detected in GO product and no GO effect on diet intake was observed, the total amount of FA in ruminal contents could not be affected by GO infusion. Hence, reductions in the proportions of $\mathrm{C} 15: 0$ and $\mathrm{C} 15: 1$ indicated that GO might reduce their de novo synthesis in the rumen. Presently, the increased proportions of C18:1, C18:2, C18:3, TVA, $c 9, t 11-C L A$, and $t 10, c 12-C L A$ in GO group, at least in part, may suggest that GO partially inhibited them from microbial biohydrogenation.

Results of the current study showed that GO increased the proportion of $c 9, t 11-\mathrm{CLA}$ in the rumen. It is known that $c 9, t 11-C L A$ is transformed from LA not linolenic acid (LNA) (Harfoot and Hazlewood, 1997). The formation of $c 9, t 11$-CLA is transient as it is biohydrogenated to TVA (Shingfield et al., 2010). Therefore, the increased proportion of $c 9, t 11$-CLA in GO group may be due to the reduced extent of biohydrogenation of $c 9, t 11-$ CLA, as indicated by the decrease of TVA/ $(c 9, t 11-\mathrm{CLA}+\mathrm{TVA})$. Bacteria falling within the Butyrivibrio group form $c 9, t 11$ CLA and TVA (Jenkins et al., 2008). Here, we investigated GO effect on the abundance of Butyrivibrio group bacteria. Although GO has a wide spectrum of antibacterial activity (Reuter et al., 1996), GO did not influence the Butyrivibrio group bacterial abundance in the rumen. Thus, GO increased $c 9, t 11$-CLA proportion probably not through its effect on total abundance of the Butyrivibrio group bacteria.

In the rumen, TVA can be further transformed to C18:0 (Harfoot and Hazlewood, 1997), and this transformation is considered rate limiting in the biohydrogenation process (Shingfield et al., 2010). Depression of this final step of the biohydrogenation process could cause the accumulation of TVA in the rumen. In the present study, the lower C18:0/ (TVA+C18:0) in GO group compared with control indicated that GO had the capacity to inhibit the final step of biohydrogenation. It is known that $B$. proteoclasticus is involved in the specific biohydrogenation of TVA to C18:0 (Harfoot and Hazlewood, 1997). Here, we found that GO tended to reduce the abundance of $B$. proteoclasticus. Therefore, the inhibitory effect of GO on the final step of biohydrogenation may be related to its antibacterial activity against $B$. proteoclasticus. However, there was a low correlation between $B$. proteoclasticus abundance and C18:0/(TVA+C18:0) in the present study. A similar relationship has been observed in previous trials (Kim et al., 2008; Huws et al., 2010). These results could indicate that the induction of $\mathrm{C} 18: 0 /(\mathrm{TVA}+\mathrm{C} 18: 0)$ was not only through the antibacterial activity of GO against B. proteoclasticus. Recent reports showed that other unknown bacteria may play a more predominant role in the final step of biohydrogenation in the rumen (Boeckaert et al., 2008; Kim et al., 2008; Huws et al., 2011). Thus, the inhibitory effect of GO on the final step of biohydrogenation may also be related to GO's antibacterial activity against other unknown 
biohydrogenating bacteria. A further understanding of the GO effect on these unknown bacteria is required to explore the inhibitory mechanism of GO in the final biohydrogenation process. Unexpectedly, the higher proportion of $\mathrm{C} 18: 0$ in GO group compared with control was also observed in this study. In addition to TVA, $c 15-$ C18:1, $t$ 15-C18:1 (biohydrogenation intermediates of LNA) and $c 9-\mathrm{C} 18: 1$ can also be transformed to $\mathrm{C} 18: 0$ in the rumen (Jenkins et al., 2008), which may in part explain the increase of C18:0 proportion in GO group. Collectively, GO has an inhibitory effect on the final step of biohydrogenation in the rumen, which may be related to its antibacterial activity against $B$. proteoclasticus and other unknown bacteria involved.

In this paper, very long-chain FA ( $\geq$ C20) mainly PUFA increased upon GO infusion. It is known that lipids are hydrolyzed into non-esterified FA (NEFA). These unsaturated NEFA then undergo biohydrogenation by microorganisms in the rumen (Jenkins et al., 2008). Thus, the increase in the proportions of very long-chain unsaturated FA may result from the decreased extent of biohydrogenation by GO. Maia et al. (2010) suggested that biohydrogenation occurred to enable the biohydrogenating bacteria to survive the bacteriostatic effects of PUFA. The sensitivity of different isolates in Butyrivibrio-related phylogenetic tree to unsaturated FA was highly variable, with $B$. proteoclasticus being much more sensitive than others (Jenkins et al., 2008). The accumulation of NEFA in the rumen can inhibit the whole process of biohydrogenation (Lourenço et al., 2010). Thus, the increased PUFA in the rumen contributed to the inhibition of the complete biohydrogenation of unsaturated FA in the diet.

\section{CONCLUSION}

In conclusion, GO infusion $(0.8 \mathrm{~g} / \mathrm{d})$ did not affect ruminal fermentation except $\mathrm{NH}_{3}-\mathrm{N}$ and $\mathrm{MCP}$, but delayed the fermentation process, suggesting its potential to maintain the ruminal environment. Garlic oil altered ruminal FA profile, with TVA and $c 9, t 11$-CLA proportions increased, but reduced TVA/( $c 9, t 11-\mathrm{CLA}+\mathrm{TVA})$ and $\mathrm{C} 18: 0 /$ (TVA+C18:0). Garlic oil inhibited the final step of biohydrogenation, and this may be related to its antibacterial activity against $B$. proteoclasticus and other unknown bacteria involved.

\section{ACKNOWLEDGEMENTS}

We are grateful to Professor John Wallace (Rowett Institute of Nutrition and Health, University of Aberdeen, UK) for providing the bacteria strain B. fibrisolvens DSM 3071. This work was supported by a grant from the Natural
Science Foundation of Jiangsu Province (BK2007721).

\section{REFERENCES}

AOAC. 1990. Official methods of analysis. 15th edn. Association of Official Analytical Chemists, Arlington, Virginia, USA.

Benchaar, C., S. Calsamiglia, A. V. Chaves, G. R. Fraser, D. Colombatto, T. A. McAllister and K. A. Beauchemin. 2008. A review of plant-derived essential oils in ruminant nutrition and production. Anim. Feed Sci. Technol. 145:209-228.

Boeckaert, C., B. Vlaeminck, V. Fievez, L. Maignien, J. Dijkstra and N. Boon. 2008. Accumulation of trans C18:1 fatty acids in the rumen after dietary algal supplementation is associated with changes in the Butyrivibrio community. Appl. Environ. Microbiol. 74:6923-6930.

Broderick, G. A. and J. H. Kang. 1980. Automated simultaneous determination of ammonia and total amino acids in ruminal fluid and in vitro media. J. Dairy Sci. 63:64-75.

Busquet, M., S. Calsamiglia, A. Ferret, P. W. Cardozo and C. Kamel. 2005a. Effects of cinnamaldehyde and garlic oil on rumen microbial fermentation in a dual flow continuous culture. J. Dairy Sci. 88:2508-2516.

Busquet, M., S. Calsamiglia, A. Ferret, M. D. Carro and C. Kamel. 2005b. Effect of garlic oil and four of its compounds on rumen microbial fermentation. J. Dairy Sci. 88:4393-4404.

Busquet, M., S. Calsamiglia, A. Ferret and C. Kamel. 2006. Plant extracts affect in vitro rumen microbial fermentation. J. Dairy Sci. 89:761-771.

Cardozo, P. W., S. Calsamiglia, A. Ferret and C. Kamel. 2004. Effects of natural plant extracts on ruminal protein degradation and fermentation profiles in continuous culture. J. Anim. Sci. 82:3230-3236.

Cardozo, P. W., S. Calsamiglia, A. Ferret and C. Kamel. 2005. Screening for the effects of natural plant extracts at different $\mathrm{pH}$ on in vitro rumen microbial fermentation of a highconcentrate diet for beef cattle. J. Anim. Sci. 83:2572-2579.

Castillejos, L., S. Calsamiglia, A. Ferret and R. Losa. 2007. Effects of dose and adaptation time of a specific blend of essential oil compounds on rumen fermentation. Anim. Feed Sci. Technol. 132:186-201

Chaves, A. V., K. Stanford, M. E. R. Dugan, L. L. Gibson, T. A. McAllister, F. Van Herk and C. Benchaar. 2008. Effects of cinnamaldehyde, garlic and juniper berry essential oils on rumen fermentation, blood metabolites, growth performance, and carcass characteristics of growing lambs. Livest. Sci. 117:215-224.

Ding, L. and A. Yokota. 2004. Proposals of Curvibacter gracilis gen. nov., sp. nov. and Herbaspirillum putei sp. nov. for bacterial strains isolated from well water and reclassification of [Pseudomonas] huttiensis, [Pseudomonas] lanceolata, [Aquaspirillum] delicatum and [Aquaspirillum] autotrophicum as Herbaspirillum huttiense comb. nov., Curvibacter lanceolatus comb. nov., Curvibacter delicatus comb. nov. and Herbaspirillum autotrophicum comb. nov. Int. J. Syst. Evol. Microbiol. 54:2223-2230.

Folch, J., M. Lees and G. Sloane-Stanley. 1957. A simple method for the isolation and purification of total lipids from animal tissues. J. Biol. Chem. 226:497-509.

Harfoot, C. G. and G. P. Hazlewood. 1997. Lipid metabolism in the 
rumen. In: The Rumen Microbial Ecosystem, 2nd Ed. (Ed. P. N. Hobson and C. S. Stewart). Chapman \& Hall, London, UK. pp. 382-426.

Huws, S. A., E. J. Kim, M. R. F. Lee, M. B. Scott, J. K. S. Tweed, E. Pinloche, R. J. Wallace and N. D. Scollan. 2011. As yet uncultured bacteria phylogenetically classified as Prevotella, Lachnospiraceae incertae sedis and unclassified Bacteroidales, Clostridiales and Ruminococcaceae may play a predominant role in ruminal biohydrogenation. Environ. Microbiol. 13:1500-1512.

Huws, S. A., M. R. F. Lee, S. M. Muetzel, M. B. Scott, R. J. Wallace and N. D. Scollan. 2010. Forage type and fish oil cause shifts in rumen bacterial diversity. FEMS Microbiol. Ecol. 73:396-407.

Iciek, M., I. Kwiecień and L. Wlodek. 2009. Biological properties of garlic and garlic-derived organosulfur compounds. Environ. Mol. Mutagen. 50:247-265.

Jenkins, T. C., R. J. Wallace, P. J. Moate and E. E. Mosley. 2008. Recent advances in biohydrogenation of unsaturated fatty acids within the rumen microbial ecosystem. J. Anim. Sci. 86:397-412.

Kemp, P., R. White and D. Lander. 1975. The hydrogenation of unsaturated fatty acids by five bacterial isolates from the sheep rumen, including a new species. J. Gen. Microbiol. 90:100-114.

Kim, E. J., S. A. Huws, M. R. F. Lee, J. D. Wood, S. M. Muetzel, R. J. Wallace and N. D. Scollan. 2008. Fish oil increases the duodenal flow of long chain polyunsaturated fatty acids and trans-11 18:1 and decreases 18:0 in steers via changes in the rumen bacterial community. J. Nutr. 138:889-896.

Kim, E. J., R. Sanderson, M. S. Dhanoa and R. J. Dewhurst. 2005. Fatty acid profiles associated with microbial colonization of freshly ingested grass and rumen biohydrogenation. J. Dairy Sci. 88:3220-3230.

Lou, Q., J. Xu, Y. Wang, C. Xue and Z. Sun. 2010. Analysis of fatty acid composition of Ulva pertusa Kjellm by gas chromatography-mass spectrometry. Chin. J. Chromatogr. 28:668-672.

Lourenço, M., E. Ramos-Morales and R. J. Wallace. 2010. The role of microbes in rumen lipolysis and biohydrogenation and their manipulation. Animal 4:1008-1023.

Lu, J., K. Huang, N. Zang, J. Li, M. Zhang and Y. Wang. 2005. Analysis of fatty acid in tissues of Penaeus vannamei cultured in sea- and fresh-waters by ultrasonic extraction-capillary gas chromatography. Chin. J. Chromatogr. 23:193-195.

Maia, M. R. G., L. C. Chaudhary, C. S. Bestwick, A. J. Richardson, N. McKain, T. R. Larson, I. A. Graham and R. J. Wallace. 2010. Toxicity of unsaturated fatty acids to the biohydrogenating ruminal bacterium, Butyrivibrio fibrisolvens. BMC Microbiol. 10:52-61.

Makkar, H. P. S., O. P. Sharma, R. K. Dawra and S. S. Negi. 1982. Simple determination of microbial protein in rumen liquor. J. Dairy Sci. 65:2170-2173.
Moon, C. D., D. M. Pacheco, W. J. Kelly, S. C. Leahy, D. Li, J. Kopečný and G. T. Attwood. 2008. Reclassification of Clostridium proteoclasticum as Butyrivibrio proteoclasticus comb. nov., a butyrateproducing ruminal bacterium. Int. J. Syst. Evol. Microbiol. 58:2041-2045.

Paillard, D., N. McKain, M. T. Rincon, K. J. Shingfield, D. I. Givens and R. J. Wallace. 2007. Quantification of ruminal Clostridium proteoclasticum by real-time PCR using a molecular beacon approach. J. Appl. Microbiol. 103:12511261.

Polan, C., J. McNeill and S. Tove. 1964. Biohydrogenation of unsaturated fatty acids by rumen bacteria. J. Bacteriol. 88:1056-1064.

Qin, W. L. 1982. Determination of rumen volatile fatty acids by means of gas chromatography. J. Nanjing Agricultural College. 4:110-116.

Reuter, H. D., H. P. Koch and L. D. Lawson. 1996. Therapeutic effects and applications of garlic and its preparations. In: Garlic: the science and therapeutic application of Allium sativum L and related species (Ed. H. P. Koch and L. D. Lawson). Williams \& Wilkins, Baltimore. pp. 135-212.

SAS Institute. 2000. SAS User's guide: Statistics. Version 8.01. SAS Institute Inc., Cary, North Carolina.

Shingfield, K. J., L. Bernard, C. Leroux and Y. Chilliard. 2010. Role of trans fatty acids in the nutritional regulation of mammary lipogenesis in ruminants. Animal 4:1140-1166.

Van Soest, P. J. J., J. B. Robertson and B. A. Lewis. 1991. Methods for dietary fiber, neutral detergent fiber, and nonstarch polysaccharides in relation to animal nutrition. J. Dairy Sci. 74:3583-3597.

Wallace, R. J. 2004. Antimicrobial properties of plant secondary metabolites. Proc. Nutr. Soc. 63:621-629.

Wanapat, M., K. Boonnop, C. Promkot and A. Cherdthong. 2011. Effects of alternative protein sources on rumen microbes. Maejo Int. J. Sci. Technol. 5:13-23.

Wanapat, M., P. Khejornsart, P. Pakdee and S. Wanapat. 2008. Effect of supplementation of garlic powder on rumen ecology and digestibility of nutrients in ruminants. J. Sci. Food Agric. 88:2231-2237.

Yang, W. Z., C. Benchaar, B. N. Ametaj, A. V. Chaves, M. L. He and T. A. McAllister. 2007. Effects of garlic and juniper berry essential oils on ruminal fermentation and on the site and extent of digestion in lactating cows. J. Dairy Sci. 90:56715681.

Zhu, Z. 2011. Effects of garlic oil on ruminal biohydrogenation, milk fatty acid profile and lipogenesis-related gene expression in mammary gland of goats. Ph.D. Thesis, Nanjing Agricultural University, Nanjing, Jiangsu.

Zoetendal, E. G., A. D. L. Akkermans and W. M. D. Vos. 1998. Temperature gradient gel electrophoresis analysis of $16 \mathrm{~S}$ rRNA from human fecal samples reveals stable and host-specific communities of active bacteria. Appl. Environ. Microbiol. 64:3854-3859. 